\title{
Growth rate and carcass value of three types of crossbred pigs fed ad libitum diets with different protein and energy contents
}

\author{
J. Kulisiewicz' ${ }^{1}$,J.L. Sokór', Anna Rekiel', R. Inarski' ${ }^{1}$ \\ and P. Lenartowicz ${ }^{1}$ \\ Warsaw Agricultural University \\ 'Department of Animal Breeding. \\ Przejazd 4, 05-840) Brwinow, Poland \\ 2 Department of Animal Nutrition and Feed Production, \\ Rakowiecka 26/30, 02-528 Warsaw, Poland
}

(Received 19 October 1994; accepted 16 February 1995)

\begin{abstract}
Fifty-four pigs of three genotypes, 25\% Polish Large White, $25 \%$ Polish Landrace (maternal genotype) and $50 \%$ Duroc or $50 \%$ Pietrain or $25 \%$ Duroc plus $25 \%$ Pietrain (paternal genotype) were fattencd from 29 to $110 \mathrm{~kg}$ body weight. The animals were fed ad libitum one of three diets containing MJ ME and g crude protein in the following amounts: 12.3 and $156 ; 12.3$ and $170 ; 13.4$ and 173 per kilogram of diet. Increasing the concentration of protein and encrgy increased cfliciency of feed conversion and ME per body gain, regardless of the type of crossbred. Genotype $x$ nutrition interaction $(P \leqslant 0.05)$ on the meat content in carcass was found. Increasing the protein as well as both protein and energy contents in the dict increased the meat content in carcass of pigs with $50 \%$ Pietrain genes, while no such response was found in the other genotypes.
\end{abstract}

KEY WORDS: growing pigs, genotype x nutrition interaction, crossbreds, Pietrain, Duroc, carcass value

\section{INTRODUCTION}

Many studies have demonstrated an interaction between pigs genotype and environmental conditions (Standal, 1984; Kanis, 1990; Englisch et al., 1990; Stern et al., 1994).

The practical consequences of this interaction for pig breeding and production as well as the best use of it are still discussed. The interaction between 
genotype and environment can significantly affect fattening performance when both the genotype and the environmental conditions vary markedly.

The studies of Cöp and Buiting (1977), Peterson (1977), Rogdakis et al. (1979) and Kanis et al. (1990) indicate that the Pietrain breed differs significantly from other European or American breeds in terms of many anatomical and physiological traits, and performance. Since the Pietrain boars may replace more widely the Duroc boars, used in Poland for crossbreeding, it seems necessary to study the performance of crossbreds of these two genotypes as affected by dietary protein and energy concentration.

\section{MATERIAL AND METHODS}

The experiment was conducted on 54 gilts and barrows, crossbreds obtained from mating 18 Large White $x$ Polish Landrace sows with 8 boars (3 each of Duroc and Pietrain and 2 Duroc $x$ Pietrain). The animals were kept in individual pens on bedding. The initial weight of the animals was $29.0 \pm 2.0 \mathrm{~kg}$, final weight $109.7 \pm 0.4 \mathrm{~kg}$. Throughout the entire experiment the pigs were fed on diets with different energy and protein contents. Group 1 received the diet containing $12.3 \mathrm{MJ} \mathrm{ME}$ and $156 \mathrm{~g}$ crude protein (CP), group 2-12.3 MJ ME and $170 \mathrm{~g} \mathrm{CP}$ $(+10 \%$ in comparison with group 1$)$, group $3-13.4 \mathrm{MJ} \mathrm{ME}(+10 \%)$ and $173 \mathrm{~g} \mathrm{CP}(+10 \%)$ per $\mathrm{kg}$ (Table 1$)$. The protein content was raised by increasing the proportion of soyabean oilmeal, while energy was added in the form of animal fat. The diets were fed ad libitum from automatic feeders. Nutritional value of feed was determined in a balance experiment ( 7 days, 18 barrows weighing about $70 \mathrm{~kg}$ ). After slaughter the primal cuts of the right half-carcass were dissected according to the methods used in Polish Pig Progeny Stations. The $\mathrm{pH}$ of meat was determined in the longissimus dorsi muscle $45 \mathrm{~min}$ and $24 \mathrm{~h}$ after slaughter.

The effect of various experimental factors was subjected to statistical analysis using the following model (all constant factors) and W. Harvey LSML 76 computer software:

$y_{i j k l}=u+a_{1}+b_{j}+c_{k}+a b_{i j}+a c_{i k}+b c_{j k}+e_{i j k l}$

where:

$\mathrm{y}=$ the value of a trait in a single pig

$\mathbf{u}=$ experimental mean

$a_{1}=$ the effect of feed $i(i=1,2,3)$

$b_{j}=$ the effect of genotype $\mathbf{j}$ of the crossbred $(j=1,2,3)$

$c_{k}=$ the effect of sex $k(k=1,2)$ 
$a b_{i j}=$ the effect of interaction of feed type $X$ genetic group

$\mathrm{ac}_{\mathrm{ik}} \mathrm{bc}_{\mathrm{jk}}=$ the effects of the remaining first degree interactions

$\mathrm{e}_{\mathrm{ijkl}}=$ residual random error

\section{RESULTS}

No statistically significant differences were found in the digestibility of nutrients depending on pigs genotype. Digestibility of protein, crude fibre and $\mathrm{N}$-free extractives did not differ between the diets while digestibility of fat in diet 3 with added fat was greater $(P \leqslant 0.01)$ than in diets 1 and $2(70.6$ vs 34.1 and $44.1 \%$ ).

Daily feed and nutrients intake are the main factors affecting fattening performance of pigs fed ad libitum. Crossbreds with $50 \%$ Pietrain genes ate less feed than the other groups during both periods and especially in the first period of the experiment, while the greatest feed intake in this period was found in crossbreds from Duroc x Pietrain sires (Table 2). The type of crossbred had no significant effect on feed intake in the second period of fattening $(65-110 \mathrm{~kg})$. Over the entire period of experiment, crossbreds with $50 \%$ Pietrain genes ate $7 \%$

TABLE 1

Composition $(\%)$ and nutritive value of diets

\begin{tabular}{|c|c|c|c|}
\hline \multirow{2}{*}{ Indices } & \multicolumn{3}{|c|}{ Diet } \\
\hline & 1 & 2 & 3 \\
\hline \multicolumn{4}{|l|}{ Components } \\
\hline protein concentrate' & 17.0 & 17.0 & 17.0 \\
\hline barley & 73.0 & 67.0 & 60.5 \\
\hline wheat bran & 10.0 & 10.0 & - \\
\hline soyabcan oilmcal & - & 6.0 & 7.5 \\
\hline fat concentrate & - & - & 15.0 \\
\hline \multicolumn{4}{|l|}{ Chemical composition } \\
\hline crude protein & 15.56 & 16.98 & 17.32 \\
\hline ether extract & 2.36 & 2.45 & 7.50 \\
\hline crude fibre & 4.48 & 4.74 & 4.31 \\
\hline $\mathrm{N}$-free extractives & 60.18 & 58.14 & 54.18 \\
\hline \multicolumn{4}{|l|}{ In $1 \mathrm{~kg}:$} \\
\hline metabolizable energy, MJ & 12.32 & 12.35 & 13.37 \\
\hline digestible protein, $\mathrm{g}$ & 119 & 132 & 138 \\
\hline lysine, $g$ & 8.2 & 9.3 & 9.6 \\
\hline
\end{tabular}

composition of protein concentrate, \%: soyabcan oilmeal 40.5 , rapeseed oilmeal " 00 " 30.0 , meat-and-bone meal 20.0, premix PT-2 3.0, dicalcium phosphate 3.0, $\mathrm{NaCl} 1.8$

2 composition of fat concentrate, $\%$ : wheat bran 66 , feed grade fat 34 
Daily mean intake: feed, metabolizable energy (ME) and digestible protein (DP)

\begin{tabular}{|c|c|c|c|c|c|c|c|}
\hline \multirow{2}{*}{ Indices } & \multicolumn{3}{|c|}{ Breed of boars } & \multicolumn{3}{|c|}{$\mathrm{D}$ i e $\mathrm{t}$} & \multirow{2}{*}{ SE } \\
\hline & Duroc & Pietrain & $\begin{array}{l}\text { Duroc } \\
\text { x Pietrain }\end{array}$ & 1 & 2 & 3 & \\
\hline \multicolumn{8}{|c|}{ Feed intake, $\mathrm{kg} / \mathrm{d}$} \\
\hline $29.65 \mathrm{~kg}$ & 2.23 & $2.13^{\mathrm{a}}$ & $2.30^{b}$ & 2.27 & 2.24 & 2.14 & 0.04 \\
\hline $65-110 \mathrm{~kg}$ & 3.14 & 2.92 & 3.10 & 3.13 & 3.16 & 2.88 & 0.10 \\
\hline $29-110 \mathrm{~kg}$ & 2.76 & 2.56 & 2.72 & 2.74 & 2.74 & 2.56 & 0.06 \\
\hline \multicolumn{8}{|l|}{ ME intake, MJ } \\
\hline $29-110 \mathrm{~kg}$ & 35.0 & 32.4 & 34.4 & 33.7 & 33.8 & 34.2 & 0.8 \\
\hline \multicolumn{8}{|l|}{ DP intake, $g$} \\
\hline $29-110 \mathrm{~kg}$ & 357 & 331 & 352 & $326^{\mathrm{A}}$ & $360^{\mathrm{B}}$ & $354^{\mathrm{B}}$ & 8 \\
\hline
\end{tabular}

$a, b-P \leqslant 0.05 ; A, B-P \leqslant 0.01$

TABLE 3

Daily liveweight gain and feed intake and metabolizable energy (ME) and digestible protein (DP) utilization per $\mathrm{kg}$ gain

\begin{tabular}{|c|c|c|c|c|c|c|c|}
\hline \multirow{2}{*}{ Indices } & \multicolumn{3}{|c|}{ Breed of boars } & \multicolumn{3}{|c|}{ D i e t } & \multirow{2}{*}{ SE } \\
\hline & Duroc & Pietrain & $\begin{array}{c}\text { Duroc } \\
x \text { Pietrain }\end{array}$ & 1 & 2 & 3 & \\
\hline \multicolumn{8}{|c|}{ Daily liveweight gain, $\mathrm{g}$} \\
\hline $29-65 \mathrm{~kg}$ & $870^{A}$ & $779^{\mathrm{B}}$ & $879^{A}$ & $770^{\AA}$ & $871^{\mathrm{B}}$ & $886^{B}$ & 26 \\
\hline $65-110 \mathrm{~kg}$ & 837 & 831 & 880 & 855 & 828 & 866 & 38 \\
\hline $29-110 \mathrm{~kg}$ & 854 & 803 & 877 & 818 & 845 & 871 & 28 \\
\hline \multicolumn{8}{|c|}{ Feed efficiency, $\mathrm{kg} / \mathrm{kg}$} \\
\hline $29-110 \mathrm{~kg}$ & 3.26 & 3.20 & 3.14 & $3.38^{\mathrm{A}}$ & $3.27^{\mathrm{A}}$ & $2.96^{B}$ & 0.09 \\
\hline \multicolumn{8}{|c|}{$\mathrm{ME}, \mathrm{MJ} / \mathrm{kg}$ gain } \\
\hline $29-110 \mathrm{~kg}$ & 41.2 & 40.5 & 39.8 & 41.6 & 40.3 & 39.6 & 1.2 \\
\hline \multicolumn{8}{|l|}{$\mathrm{DP}, \mathrm{g} / \mathrm{kg}$ gain } \\
\hline $29-110 \mathrm{~kg}$ & 421 & 414 & 406 & 402 & 430 & 410 & 12 \\
\hline
\end{tabular}

$A, B-P \leqslant 0.01$ 
less feed than the other crossbreds, but this difference was statistically not significant.

The greater protein content in the diet 2 did not affect significantly feed intake while increasing the energy concentration by adding fat to diet 3 resulted in a $7 \%$ decrease of feed intake.

Raising the protein content in the diets 2 and 3 increased the daily intake of this nutrient in all pigs $(P \leqslant 0.01)$.

In spite of lower feed intake, protein intake in the $50 \%$ Pietrain crossbreds fed on diets 2 and 3 was similar as in other crossbreds fed on diet 1 with lower protein content.

The weight gains of the animals were high and equalled $845 \mathrm{~g}$ daily for the entire period of fattening (Table 3 ).

Increasing the protein content in diet 2 increased $(P \leqslant 0.01)$ the rate of gain of all crossbreds only in the first period of experiment (Table 3 ). The response to the higher protein level in the second period of fattening was much less pronounced.

Only simultaneous increasing the protein and energy concentrations in the diet improved $(\mathrm{P} \leqslant 0.01)$ efficiency of feed utilization (Table 3 ), while increasing only the protein content resulted in lower efficiency of protein utilization per kilogram gain.

The weight of longissimus dorsi, the content of meat in ham and in the carcass (per cent) were greater $(P \leqslant 0.01)$ while that of fat was lower in $50 \%$ Pietrain crossbred than in other crossbreds. The crossbreds of Duroc $x$ Pietrain sires had meat traits intermediate between those of crossbreds sired by Pietrain or Duroc

TABLE 4

Carcass value of pigs slaughtered at $109.7 \pm 0.4 \mathrm{~kg}$

\begin{tabular}{|c|c|c|c|c|c|c|c|}
\hline \multirow{2}{*}{ Indices } & \multicolumn{3}{|c|}{ Breed of boars } & \multicolumn{3}{|c|}{ Die t } & \multirow{2}{*}{$\mathrm{SE}$} \\
\hline & Duroc & Pietrain & $\begin{array}{l}\text { Duroc } \\
\times \text { Pietrain }\end{array}$ & 1 & 2 & 3 & \\
\hline Meat of loin, $\mathrm{kg}$ & $2.09^{\wedge}$ & $2.76^{\mathrm{B}}$ & $2.30^{\wedge}$ & 2.33 & 2.34 & 2.48 & 0.07 \\
\hline Meat of ham, $\mathrm{kg}$ & $6.08^{\star}$ & $7.39^{\mathrm{B}}$ & $6.26^{A}$ & 6.42 & 6.47 & 6.85 & 0.14 \\
\hline $\begin{array}{l}\text { Meat in primal } \\
\text { cuts, } \%^{*}\end{array}$ & $55.1^{\wedge}$ & $66.2^{\mathrm{B}}$ & $59.4^{c}$ & 59.5 & 60.0 & 61.2 & 0.8 \\
\hline $\begin{array}{l}\text { Fat in primal } \\
\text { cuts, } \%\end{array}$ & $29.8^{A}$ & $20.1^{\mathrm{B}}$ & $25.6^{c}$ & 26.0 & 25.4 & 24.3 & 0.9 \\
\hline $\mathrm{pH}_{1}$ & $6.30^{\mathrm{A}}$ & $5.95^{\mathrm{kh}}$ & $6.19^{*}$ & 6.11 & 6.17 & 6.17 & 0.07 \\
\hline $\mathrm{pH}_{24}$ & 5.60 & 5.51 & 5.50 & 5.50 & 5.56 & 5.55 & 0.03 \\
\hline
\end{tabular}

$a, b-P \leqslant 0.05 ; A, B, C-P \leqslant 0.01$

* - crossbred $x$ diet interaction $(P \leqslant 0.05)$. Explanation see Table 5 
TABLE 5

Crossbred $\mathrm{x}$ diet interaction for meat content in the carcass, $\%$

\begin{tabular}{lccc}
\hline Breed of boars & \multicolumn{3}{c}{ D i e t } \\
\hline Duroc & 55.6 & 2 & 3 \\
Pietrain & 63.0 & 53.9 & 55.9 \\
Duroc x Pietrain & 60.0 & 66.0 & 69.6 \\
\hline
\end{tabular}

boars, although the leanness of the most valuable cuts of carcass resembled more Duroc than Pietrain.

The very high meat content of the $50 \%$ Pietrain crossbreds was accompanied by an unfavourable reduction in meat $\mathrm{pH}$ measured $45 \mathrm{~min}$ after slaughter. Increasing the concentration of protein and energy in the diet resulted in deterioration of this parameter in crossbreds with $50 \%$ Pietrain genes, most likely indirectly by increasing the meat content.

Increasing the concentration of nutrients in the diet did not affect the leanness of the crossbreds with $50 \%$ Duroc genes or those with $25 \%$ Duroc and $25 \%$ Pietrain genes while increasing both protein and protein and energy concentration caused an increase in the meat content of carcass in crossbreds with $50 \%$ Pietrain genes. This difference explains the observed significant $(\mathbf{P} \leqslant 0.05)$ interaction between type of diet $x$ type of crossbred for the trait of meat percentage in the carcass (Table 5).

\section{DISCUSSION}

Planning the experimental design, we expected that the crossbreds having $50 \%$ Pietrain genes would eat less feed than other genotypes (Peterson, 1977), especially than the Duroc breed, which is characterized by a great appetite (Cöp and Buiting, 1977).

Kanis (1990) demonstrated the marked effect of the voluntary feed intake on the performance of pigs fed ad libitum. Thus it should have been expected that the crossbreds with a large proportion of Pietrain genes will respond favourably to the increased concentration of energy and protein in the diet. Due to the differences in carbohydrate and fat metabolism between Pietrain (Rogdakis et al., 1979; Berschauer et al., 1982) and other breeds the increased fat deposition should not be expected. This was confirmed in our experiment. The pigs with $50 \%$ Pietrain genes ate $7 \%$ less feed than the others. These crossbreds on diet 3 , with the increased protein and energy contents, ate a similar amount of nutrients as pigs of the other genotypes on diet with lower concentration of protein and 
energy (diet 1). Increasing the concentration of nutrients, i.e. protein (diet 2) or protein and energy (diet 3 ) influenced favourably daily gains and feed efficiency ratio. The response of different genotypes was similar, and the genetic group $\mathrm{x}$ type of feed interaction for these traits was not significant.

These results are in agreement with those obtained in fattening the same type of crossbreds on similar diets fed according to standars (Sokół et al., 1994). Also other authors (Holmes et al., 1983; Kowach et al., 1984) have not found significant interactions between different genotypes of pigs and the feeding level or dietary energy concentration (Savidge et al., 1984) for body gain and feed utilization.

There was, however, a significant $(P \leqslant 0.05)$ effect of genotype $\mathrm{x}$ nutrition interaction on the percentage of meat in the carcass. The higher energy and protein concentrations increased the leanness of the $50 \%$ Pietrain crossbreds, while in other genotypes the ratio of meat to fat was unchanged or was slightly lower.

Peterson (1977) found that Pietrain pigs should be given the diets with higher protein level than the German Landrace to take advantage of their capacity to meat production. The results of our study indicate that it is advisable to increase the concentration of both protein and energy in the diets for fattened crossbreds of Polish maternal breeds and Pietrain, fed ad libitum. Campbell et al. (1985) and Chabiera et al. (1994) also found that in young pigs with a high ability to protein deposition in the body, a diet with a higher energy protein or lysine content can be used without deterioration of its utilization or increasing fat deposition. Our results are in agreement with results obtained by these authors.

\section{SUMMARY}

Increased protein concentration, especially protein and energy, in the feed increased the growth rate of pigs regardless of their genotype, while the effect of the interaction of genotype $x$ nutrition on this trait was nonsignificant.

A significant effect of interaction of genotype $x$ nutrition on the meat content in the carcass was found. Increasing the digestible protein content from about 12 to $14 \%$ and the energy concentration from 12.3 to $13.3 \mathrm{MJ} \mathrm{ME}$ in $1 \mathrm{~kg}$ of the diet given ad libitum increased the meatiness of the crossbreds with $50 \%$ Pietrain genes, but had no effect on the meatiness of the crossbreds with Duroc genes.

Crossbreds with $50 \%$ Pietrain genes, as compared with those with Duroc genes, were characterized by a greater meat content in carcass, slower growth rate, especially in the first period of fattening $(29-65 \mathrm{~kg})$, lower $\mathrm{pH}_{45}$ and lower appetite during both periods of fattening. 


\section{REFERENCES}

Berschauer F., Ehrensvard U., Gaus G., Menk K., 1982. Vergleichende Stoffwechseluntersuchungen an Ferkeln der Rasse Deutsche Landrasse, Pietrain und Edelschwein. Züchtungskunde 54, 46-62

Campbell R.G., Taverner M.R., Curie D.M., 1985. The influence of feeding level on the protein requirement of pigs between $20-45 \mathrm{~kg}$ live weight. Anim. Prod. 40, 497-505

Chabiera K., Kotarbińska M., Raj S., Fandrejewski H., Weremko D., 1994. Effect of intake of metabolizable energy and lysine on the performance and chemical body composition of growing pigs (in Polish). Proceedings of Symposium "Recent Advances in Swine Nutrition", Jabłonna, pp. $38-41$

Cöp W.A.G., Buiting G.A.J., 1977. Feed intake in six lines of pigs and its influence on growth and carcass traits. Anim. Prod. 25, 291-304

English H.G., Fritzsche J., Hagemann L., Redel H., Herrendorfer G., 1990. Experimente zu Genotyp-Umwelt-Wechselwirkungen beim Schwein. Arch. Anim. Breed. 33, 261-269

Holmes C.W., Smith W.C., Moore Y.F., 1983. Some comparative aspects of the energy and nitrogen metabolism of Large White and Duroc female pigs during growth. N.Z.J. Agric. Res. 26, 447-450

Kanis E., 1990. Effect of food intake capacity on genotype by feeding regimen interactions in growing pigs. Anim. Prod. 50, 343-351

Kanis E., Nieuwhof G.J., K.H. der Graaf, 1990. Effect of recombinant porcine somatotropin on growth and carcass quality in growing pigs interaction with genotype, gender and slaughter weight. J. Anim. Sci. 68, 1193-1200

Kowach G., Horn P., Vagyon L., Meszaros Z., 1987. Effect of feeding method on fattening performance and carcass quality in different genotypes of hybrid swine. Proceeding 38th Annual Meeting EAAP, Lisbon, P.5.35

Petersen U., 1977. Vergleichende Untersuchungen über die Schlachtkorperzusammensetzung und die Ausbildung von Organen bei Schweinen der Rassen Pietrain und Deutsche Landrasse unter Berücksichtigung der Proteinversorgung. Züchtungskunde 50, 208-219

Rogdakis E., Ensinger U., Faber H., 1979. Hormonspiegel im Plasma und Enzymäktivitaten im Fettgewebe von Pietrain und Edelschwein. Z. Tierzucht. ZuchtBiol. 96, 108-119

Savidge J.A., Cole D.J.A., Lewis D., 1984. A study of dietary energy density and genotype interaction on voluntary food intake on the grower pig. Anim. Prod. 38, 535

Standal N., 1984. Interaction Genotyp-Test Millieu estiemiert von Stations und Feldtest Daten. Procceding 35th Annual Meeting EAAP, Hague, GP.1.7

Sokół J.L., Sawosz E., Iniarski R., Chachułowa J., 1994. The fattening results of three types of crossbreed pigs fed diets with different level of protein and energy (in Polish). Proceedings of Symposium "Recent Advances in Swine Nutrition", Jablonna, pp. 34-37

Stern S., Johansson K., Rydhamer L., Andersson K., 1994. Performance testing of pigs for lean tissue growth rate in selection experiment with low and high protein diets. Acta Agric. Scand. Sect. A, Anim. Sci. 44, 1-7 


\section{STRESZCZENIE}

Wyniki tuczu trzech typów mieszańców świń żywionych do woli dawkami o zróżnicowanym poziomie bialka i energii

Pięćdziesiąt cztery tuczniki trzech różnych genotypów: $25 \%$ wielka biala polska, $25 \%$ polska biała zwisłoucha (genotyp matck) i 50\% Duroc lub 50\% Pietrain albo 25\% Duroc i $25 \%$ Pietrain (genotyp ojców) tuczono od 29 do $110 \mathrm{~kg}$ masy ciala. Zwicrz̨̧ta żywiono do woli trzema rodzajami dawek zawierających (MJ ME, g białka ogólnego): 12.3, 156; 12.3, 170 i 13.4, $173 \mathrm{w} 1 \mathrm{~kg}$ paszy, odpowiednio.

Zwiększenie poziomu białka w dawce spowodowało wzrost przyrostów dziennych z 818 do $845 \mathrm{~g}$, a jednoczesne zwiększenie koncentracji energii i białka dalszy wzrost przyrostów do $871 \mathrm{~g}$ i zmniejszenie zużycia paszy z 3.38 do $3.27 \mathrm{i} 2.96 \mathrm{~kg}$ na $1 \mathrm{~kg}$ przyrostu, przy braku istotnej interakcji genotyp $x$ żywienie.

Stwierdzono wpływ $(P \leqslant 0.05)$ interakcji genotyp x żywicnic na zawartość mięsa w wyrębach podstawowych. Wzrost koncentracji białka, a także białka i energii w dawkach spowodowal wzrost zawartości mięsa u tuczników z 50\% udziałem genów rasy Pietrain, przy braku takiej reakcji u pozostalych genotypów. 